\author{
KAMILA ZióŁKOWSKA-WEISS \\ Uniwersytet Pedagogiczny w Krakowie, Polska \\ Pedagogical University of Krakow, Poland
}

\title{
EWELINA HARAS
}

Uniwersytet Jagielloński, Kraków, Polska

Jagiellonian University, Krakow, Poland

\section{Aktywność turystyczna argentyńskiej Polonii na przykładzie mieszkańców Buenos Aires - w świetle badań pilotażowych}

\section{Tourist Activity of the Polish Argentines as Exemplified by the Residents of Buenos Aires - an Outline of Pilot Studies}

\begin{abstract}
Streszczenie: Głównym celem badań jest określenie aktywności turystycznej argentyńskiej Polonii na przykładzie mieszkańców Buenos Aires. W 2017 i 2018 roku przeprowadzone zostały pilotażowe badania ankietowe, dzięki którym uzyskana została informacja dotycząca długości trwania podróży, częstotliwości podróżowania, wyboru środka transportu, sposobu organizacji podróży, tego, z kim argentyńska Polonia podróżuje, gdzie się zatrzymuje podczas podróży oraz jakie są główne motywy podróżowania. Buenos Aires jest głównym skupiskiem Polonii w Argentynie, jednocześnie jest to jeden z większych ośrodków polonijnych, mieszczących się Ameryce Południowej (Malinowski, 2005: 324). Jak podaje Ambasada Polski w Buenos Aires, szacuje się, że w samej stolicy Argentyny mieszka około 18-20 tys. osób pochodzenia polskiego. Wśród Polonii argentyńskiej dominuje turystyka wypoczynkowa, najważniejszym regionem wypoczynkowym jest wybrzeże La Platy. Na wybrzeżu tym dużą popularnością cieszą się kąpieliska Mar de Plata i Miramar (Kurek, 2011: 540). Jak wykazały przeprowadzone pilotażowe badania ankietowe, Polonia argentyńska jest aktywna turystycznie. Około 40 \% ankietowanych podróżuje dwa-trzy razy w ciągu roku. Najwięcej osób podróżuje w celach poznawczych i wypoczynkowych. Większość ankietowanych to osoby, które organizują swoje podróże samodzielnie, a podczas podróży najchętniej zatrzymują się u rodziny i przyjaciół.
\end{abstract}

Abstract: The main purpose of the research is to determine the tourist activity and destinations of the Polish Argentines as exemplified by the residents of Buenos Aires. For this purpose, pilot surveys were conducted in 2018, thanks to which information was obtained regarding the duration of the journey, frequency of travelling, choice of the means of transport, way of travelling, who the Polish Argentines travel with, where they stop during the trip and what the main motives and travel destinations are. Buenos Aires is the main concentration of Polonia in Argentina, at the same time it is one of the largest Polish community centres located in South America. According to the Polish Embassy in Buenos Aires, it is estimated that about 18-20,000 people of Polish origin live only in the capital of Argentina. Among the Polish Argentines, recreational tourism dominates and the most important holiday region is the coast of La Plata. As confirmed by the conducted pilot surveys, Polish Argentines are active considering the aspect of tourism. About 40\% of the respondents travel 2-3 times a year. Most people travel for cognitive and recreational purposes. Most of the respondents are people who organise their trips by themselves, and during the journeys they most often stay with friends and family. 
Słowa kluczowe: aktywność i destynacje turystyczne; Argentyna; Buenos Aires; Polonia; turystyka Keywords: activity and tourist destination; Argentina; Buenos Aires; Polish people; tourism

Otrzymano: 16 stycznia 2019

Received: 16 January 2019

Zaakceptowano: 2 luty 2020

Accepted: 2 February 2020

Sugerowana cytacja / Suggested citation:

Ziółkowska-Weiss, K., Haras, E. (2020). Aktywność turystyczna argentyńskiej Polonii na przykładzie mieszkańców Buenos Aires - w świetle badań pilotażowych. Prace Komisji Geografii Przemysłu Polskiego Towarzystwa Geograficznego, 34(1), 108-123. doi: 10.24917/20801653.341.8

\section{WSTĘP}

W ostatnich 50 latach turystyka stała się jednym z największych i najszybciej rozwijających się sektorów gospodarki na świecie. Liczba osób wyjeżdżających za granicę osiągnęła ponad 1,2 mld w skali roku (UNWT0, 2016). Dzięki temu turystyka tworzy około 11\% światowego PKB i zapewnia co 11 miejsce pracy. Nie ma wątpliwości, że gwałtowny rozwój turystyki niesie za sobą duże korzyści. Turystyka przyczynia się do wzrostu zatrudnienia, międzynarodowego przepływu osób i przedsiębiorczości, a także do rozwoju obszarów miejskich i wiejskich w wielu krajach i regionach (UNWTO, 2016). Turystyka ma korzystny wpływ na zmniejszenie ubóstwa, a także daje możliwość poznania innych kultur i tradycji, co niesie za sobą lepsze zrozumienie innych kultur oraz wzajemne poszanowanie i tolerancję.

Aktywność turystyczna to pojęcie, które coraz częściej można spotkać w różnych opracowaniach socjologicznych, teoretycznych, ekonomicznych, geograficznych, pedagogicznych, psychologicznych (Ziółkowska-Weiss, 2018). Jak pisze Olaf Rogalewski „każdy walor turystyczny posiada pewien okres aktywności turystycznej, czyli okres w ciągu roku, w jakim może być wykorzystywany albo zwiedzany przez turystów" (Ziółkowska-Weiss, 2018).

Bogactwo i różnorodność walorów przyrodniczych Ameryki Południowej, zwłaszcza terenów górskich, sprawiają, że Argentyna od wielu lat odgrywa istotną rolę w rozwoju turystyki na południowoamerykańskim kontynencie. Wyjątkowo urozmaicony krajobraz Andów, związany m.in. z powszechnie występującymi formami glacjalnymi, sprzyja uprawianiu turystyki górskiej: pieszym wycieczkom, trekkingowi, turystyce narciarskiej oraz wyprawom alpinistycznym (Groch, Mydela, 1999: 372). Jednym z najbardziej atrakcyjnych turystycznie krajów Ameryki Południowej jest Argentyna. W artykule przedstawione zostaną badania pilotażowe nad aktywnościami i destynacjami turystycznymi argentyńskiej Polonii na przykładzie mieszkańców Buenos Aires. Argentyna to bardzo zróżnicowany krajobrazowo, kulturowo i geograficznie kraj. Wśród Polonii argentyńskiej dominuje zdecydowanie turystyka wypoczynkowa, najważniejszym regionem wypoczynkowym jest wybrzeże La Platy. Na wybrzeżu tym dużą popularnością cieszą się kąpieliska Mar de Plata i Miramar (Kurek, 2011). Jednym z najchętniej odwiedzanych miejsc jest stolica kraju - Buenos Aires, która ma bardzo dobrze rozwiniętą bazę noclegową i gastronomiczną oraz przyciąga piękną architekturą i zabytkami. Najlepszy czas na przyjazd do Argentyny to okres wiosny, który trwa od września do grudnia. Wtedy nie panują jeszcze wielkie upały, ale jest ciepło i przyjemnie, co tworzy idealne warunki do uprawiania różnych form turystki. 


\section{PRZEGLĄD LITERATURY}

Aktywność turystyczna jest pojęciem, które coraz częściej można spotkać w różnych opracowaniach teoretycznych, ekonomicznych, socjologicznych, psychologicznych, pedagogicznych czy geograficznych. Przy jej definiowaniu napotyka się wiele trudności, które mogą wynikać z interdyscyplinarności tego zjawiska. Już samo pojęcie turystyki jest wieloznacznie określane w literaturze przedmiotu. Trudno jest również zdefiniować termin „aktywność”, który jest określeniem bardzo ogólnym.

Aby lepiej zrozumieć pojęcie aktywności turystycznej, autorki tekstu korzystały z artykułu Wiesława Alejziaka pt. Aktywność turystyczna: Międzynarodowe i krajowe zróżnicowanie oraz kwestia wykluczenia społecznego (2011). Autor wyjaśnia w nim pojęcie aktywności turystycznej, przyjmując, że jest to „ogół czynności i działań ludzi, związanych z ich uczestnictwem w turystyce”. Taka też definicja aktywności turystycznej została przyjęta w niniejszym opracowaniu.

Autorki korzystały z Przewodnika po Argentynie wydanego przez National Geographic (2011), dzięki czemu udało im się uzupełnić wiedzę na temat walorów turystycznych Argentyny. Innym cennym źródłem dotyczącym tego tematu był przewodnik Podróże marzeń - Argentyna, w którym bardzo dokładnie został opisany każdy region tego kraju.

Przygotowując niniejsze opracowanie, autorki dokładnie przestudiowały także literaturę dotyczącą emigracji polskiej do Argentyny. Wśród publikacji wykorzystanych w artykule znalazła się książka Eugeniusza Curusia pt. Polacy w Argentynie (1978), w której autor opisuje poszczególne etapy emigracji polskiej do Argentyny: emigrację wojskowo-polityczną w XIX wieku, początki osadnictwa rolniczego, emigrację w okresie międzywojennymi, w czasie II wojny światowej oraz w pierwszych latach powojennych.

Innym źródłem, jakie zostało wykorzystane w artykule, jest książka pod redakcją naukową Zygmunta Kruczka pt. Kraje pozaeuropejskie - zarys geografii turystycznej (2010). Dzięki niej autorki zdobyły informacje na temat warunków naturalnych, rozwoju turystyki oraz ruchu turystycznego w Argentynie.

Przy opisie organizacji polonijnych działających w Argentynie autorki korzystały z książki Mariusza Malinowskiego pt. Ruch polonijny w Argentynie i Brazylii w latach 1989-2000 (2005). Autor opisuje w niej i pierwsze organizacje polskie powstałe w Argentynie, i te współczesne.

Pomocnym źródłem informacji o argentyńskiej Polonii była książka Mirosława Olszyckiego pt. Ziemia czerwonych drzew - Polacy z Ameryki Południowej (2014). Zawiera ona zbiór informacji na temat osadnictwa polskiego w Argentynie, z wyszczególnieniem osadnictwa w Misiones. Autor opisuje także Polaków i polskie organizacje działające w Buenos Aires, porusza też tematykę roli Kościoła katolickiego w życiu argentyńskiej Polonii.

Stanisław Pyzik, autor książki pt. Polacy w Argentynie i w innych krajach Ameryki Południowej (2004), przedstawił w niej rys historyczny emigracji polskiej do Ameryki Południowej i do Argentyny (w dwóch rozdziałach: Polacy w Ameryce Południowej oraz Polacy w Argentynie). Autor w szczególny sposób skupił uwagę na przybliżeniu takich postaci, jak Józef Białostocki, Gustaw Jasiński oraz inni Polacy, którzy wiele wnieśli w życie środowiska polonijnego w Argentynie. 
Polonia argentyńska $w$ piśmiennictwie polskim pod redakcją Barbary Romanowskiej-Kindziuk (2004) to zbiór opracowań o historii emigracji polskiej w Argentynie. Porusza kwestie emigracji zarobkowej oraz późniejszej emigracji po II wojnie światowej. Publikacja ta przybliża także życie codzienne, jakie prowadzili pierwsi osadnicy w Argentynie.

\section{PRZEBIEG BADAŃ ORAZ ZAKRES CZASOWY I PRZESTRZENNY BADAŃ EMPIRYCZNYCH}

Głównym celem badań było określenie aktywności i destynacji turystycznych Polonii argentyńskiej. W ramach pracy przeprowadzone zostały badania ankietowe wśród społeczności polskiej zamieszkującej Argentynę, dzięki czemu uzyskano informacje na temat kierunków podróży wybieranych przez tę społeczność, długości trwania podróży, środków transportu, jakimi argentyńska Polonia podróżuje, z kim podróżuje, gdzie się zatrzymuje podczas podróży oraz jakie są główne motywy podróżowania.

Prezentowane w artykule dane są oparte na kameralnych i terenowych badaniach, które były prowadzone przez autorki w latach 2017-2018. Były to badania pilotażowe, które - poza poznaniem turystycznych preferencji argentyńskiej Polonii - miały zweryfikować, czy przygotowany kwestionariusz ankietowy jest w całości zrozumiany przez ankietowanych. Celem kwestionariusza było także sprawdzenie, jakie inne, sugerowane przez respondentów pytania mogłyby się znaleźć w kwestionariuszu, a które autorzy w pierwszym, próbnym badaniu pominęli. Badanie pilotażowe pozwoliło wstępnie zweryfikować wiedzę o badanym środowisku oraz sformułować zestaw pytań, na które to badanie miało odpowiedzieć. Podstawową funkcją badania pilotażowego było uzyskanie pewnej wstępnej, niekompletnej wiedzy o badanej zbiorowości, która dostarczyła założeń do dalszych pytań, a także poprawi efektywność badania głównego, które autorki zamierzają kontynuować na większej populacji polskiej zbiorowości w Argentynie. Dzięki wstępnym badaniom autorki rozbudowały kwestionariusz ankietowy o pytania, które sugerowali respondenci, i które zostaną zadane podczas badań właściwych.

Badanie pilotażowe miało również na celu potwierdzenie przydatności metod i narzędzi badawczych wykorzystanych w danym środowisku oraz ocenę zasadności doboru określonych metod badawczych (Nowak, 2007).

Głównym narzędziem badawczym były przeprowadzone tradycyjną metodą kwestionariusze ankietowe. Kwestionariusz ankietowy jest metodą pozwalającą zdobyć niezbędną wiedzę przez pytanie wybranych osób za pośrednictwem wydrukowanej listy pytań i analizowanie otrzymanych odpowiedzi (Ziółkowska-Weiss, 2017a). Może składać się z pytań zamkniętych, otwartych i skategoryzowanych.

Kwestionariusz ankietowy sporządzony przez autorki artykułu zawierał pytania dotyczące: motywów podróżowania, częstotliwości wyjazdów, sposobu organizacji wyjazdów, destynacji turystycznych, atrakcji turystycznych Argentyny. Został sporządzony w dwóch wersjach językowych: polskiej oraz hiszpańskiej w celu ułatwienia zrozumienia go zwłaszcza przez młodszą część społeczności polskiej, która słabiej posługuje się językiem polskim. Badania ankietowe prowadzone były w obrębie Buenos Aires.

Istnieją różne formy badania pilotażowego. Badanie takie może być prowadzone na małych i dużych próbach. Wielkość próby powinna być taka, aby zapewnić istotność statystyczną wyników. Jednak zazwyczaj badania pilotażowe są przeprowadzane na 
małych próbkach. Praktyka pokazuje, że liczba respondentów najczęściej nie przekracza 100 osób (Nowak, 2007). I w tym przypadku grupę badawczą stanowiło łącznie 50 osób. Autorki przyjęły, że przebadają około 0,03\% populacji argentyńskiej Polonii zamieszkującej Buenos Aires z liczby 15 tys., co daje 50 osób. Już w badaniach pilotażowych dokonany został podział ze względu na wiek respondentów w celu poznania preferencji turystycznych w poszczególnych grupach wiekowych. Pierwszą grupą badanych była młodzież wieku 16-19 lat, drugą grupę stanowiły osoby w wieku 20-24 lata. W trzeciej grupie były osoby w wieku 25-29 lat, w czwartej - 30-39 lat, w piątej 40-49 lat. Szósta to osoby wieku 50-60 lat, siódma - 61-70 lat. Autorki pracy w ankiecie uwzględniły również ósmą grupę wiekową, ankietowanych powyżej 70 roku życia, jednakże w badaniach pilotażowych nie było przedstawicieli tej grupy wiekowej.

Autorki przeprowadziły także liczne wywiady wśród argentyńskiej, polonijnej społeczności w Buenos Aires. Wywiad jest bardzo popularną metodą badania, dostarcza wielu cennych informacji na temat badanych populacji. Dużą zaletą tego narzędzia badawczego jest bezpośredni kontakt z osobą badaną, dzięki czemu można uzyskać więcej informacji na dany temat (Ziółkowska-Weiss, 2017b). Autorki przeprowadzały wywiady z ojcem Olafem Bochnakiem z Polskiej Misji Katolickiej w Martin Coronado, które trwały cyklicznie w latach 2017-2018, dzięki czemu uzyskiwały aktualne informacje na temat argentyńskiej Polonii. Kilkakrotnie rozmawiały z ojcem Jerzym Twarogiem, rektorem Polskiej Misji Katolickiej w Martin Coronado. Ojciec Jerzy Twaróg na bieżąco dostarczał autorkom najświeższe materiały z uroczystości polonijnych w Buenos Aires oraz Martin Coronado. Dzięki pomocy ojca Jerzego udało się również porozmawiać z panem Michałem Świetlikiem z Ambasady Polski w Buenos Aires, co pomogło autorkom w zdobyciu wiarygodnych danych na temat liczebności osób polskiego pochodzenia zamieszkujących stolicę Argentyny.

Dane uzyskane $\mathrm{z}$ analizy przeprowadzonych badań zostały policzone, zestawione i przedstawione na wykresach. Buenos Aires jest głównym skupiskiem Polonii w Argentynie, jednocześnie jest to jeden z większych ośrodków polonijnych w Ameryce Południowej (Malinowski, 2005). Autorki wybrały Buenos Aires jako miejsce przeprowadzania badań naukowych właśnie ze względu na duże skupisko polonijne w stolicy Argentyny.

\section{HISTORIA SPOŁECZNOŚCI POLSKIEJ W ARGENTYNIE}

Początek emigracji polskiej do Brazylii i Argentyny przypada na XIX wiek. Jej przyczynami były trudna sytuacja polityczna w Polsce spowodowana utratą niepodległości oraz kryzys gospodarczy (Curuś, 1978). Władze krajów Ameryki Południowej bardzo chętnie przyjmowały emigrantów, gdyż dążyły do rozwoju gospodarczego, a w tym celu potrzebne były ręce do pracy i uprawiania ziemi. Jak pisze M. Paradowska (1984), pierwsi Polacy przybyli do Argentyny w latach 1812-1813, wzięli oni udział w walkach o wyzwolenie Argentyny, która znajdowała się pod panowaniem Hiszpanii. Następna fala uchodźców z Polski przybyła do Argentyny po upadku powstania listopadowego, w tym okresie przybyli do Argentyny m.in.: Ignacy Domeyko, Edmund Strzelecki, a także Maksymilian Rymarkiewicz, który był lekarzem (Pyzik, 2004). Upadek powstania styczniowego w 1864 roku doprowadził do przyjazu kolejnej fali emigrantów. Przybyli wówczas lekarze z Polski, m.in. Julian Jurkowski, dzięki któremu w Argentynie powstało 
pierwsze sanatorium, gdzie leczono choroby płucne, wykładowca Karol Nowakowski, uczący matematyki, i kilku innych zdolnych Polaków (Paradowska, 1984).

W 1897 roku dociera do Argentyny 14 rodzin chłopskich z Galicji (Wróbel, 2004). Osiedlają się one w prowincji Misiones w północno-wschodniej części kraju. Każda z przybyłych rodzin otrzymała działkę, z której mogła korzystać, a należność za nią można było spłacać w ratach. Jak pisze M. Olszycki (2014), na początku Polakom brakowało praktycznie wszystkiego, począwszy od zwierząt, po narzędzia, ubrania leki i żywność. W miejscowości Apostoles powstało największe skupisko polonijne w Argentynie, osadnicy sprowadzali swoje rodziny i tak powstała kolejna polska kolonia w miejscowości Azarra (Romanowska-Kindziuk, 2004).

W późniejszych latach w Misiones pojawiły się kolejne polskie kolonie, m.in. w Corpus Christi, Guarany, Obera, Polana, Capom Grande, Capom Verdze, Wanda, Poscadas (Olszycki, 2014). Oprócz Polaków na terenie prowincji Misiones osiedlali się także Rosjanie, Żydzi, Ukraińcy, Czesi, Węgrzy, Serbowie, Słowacy (Olszycki, 2014). M. Olszycki (2014) pisze, że w latach trzydziestych Misiones zamieszkiwało 800 rodzin polskich lub polskiego pochodzenia, co stanowiło około 10\% liczby ludności całej prowincji. Nie wszyscy Polacy, którzy przybywali do Argentyny, osiedlali się w Misiones, spora ich część pozostawała w Buenos Aires. Ostatnia fala emigracyjna, która miała miejsce w latach 1945-1947, przywiodła do Argentyny wielu artystów (Paradowska, 1984). Założyli oni Koło Artystów Plastyków. W roku 1939 do Argentyny przyjechał pisarz Witold Gombrowicz.

Ważną oazą polskości w Argentynie jest Polski Ośrodek Katolicki w Martin Coronado w Buenos Aires. Ośrodek powstał, 1950 roku z inicjatywy ojców Andrzeja Smolenia i Justyniana Maciaszka. Znajduje się tutaj kościół i klasztor ojców bernardynów pw. Matki Bożej Królowej Polski, a przy klasztorze działa Polska Szkoła Sobotnia im. Tysiąclecia Chrztu Polski, w której dzieci uczą się języka polskiego, historii, geografii i religii (Wróbel, 1991). W 1977 roku został wybudowany, dzięki dużej pomocy argentyńskiej Polonii, Dom Spokojnej Starości dla osób, które mają polskie pochodzenie. Domem tym zarządzają siostry albertynki, opiekują się starszymi, dbają o ich wyżywienie, sprawują też opiekę medyczną. Klasztor ojców bernardynów w Martin Coronado to serce polonijnego życia w Argentynie.

W 1954 roku z inicjatywy ojca Justyniana Maciaszka zakupiono działkę w Martin Coronado (dzielnica Buenos Aires) i rozpoczęto starania o powstanie nowego duszpasterskiego ośrodka polskiego z własną kaplicą, klasztorem, szkołą, biblioteką i salą parafialną (Malinowski, 2005). Po śmierci ojca Maciaszka ośrodek zaczęto nazywać Maciaszkowem i tak jest po dzień dzisiejszy. W Polskim Ośrodku Katolickim odbywają się msze święte oraz polskie nabożeństwa niedzielne.

Dzięki uprzejmości oraz za pośrednictwem ojców i nauczycieli uczących w szkole sobotniej działającej przy misji udało się dotrzeć do polskiej społeczności w Buenos Aires i przeprowadzić zarówno badania ankietowe, jak i wywiady z przedstawicielami polskiej społeczności w Buenos Aires. Argentyna to jedyne miejsce na świecie, gdzie obchodzi się Dzień Osadnika Polskiego. Jest to święto narodowe upamiętniające przybycie pierwszych osadników polskich na argentyńskie ziemie. Z tej okazji 8 czerwca każdego roku rozpoczyna się tydzień imprez kulturalnych w Buenos Aires i okolicy. Społeczność polska jest darzona przez Argentyńczyków dużą sympatią. 


\section{AKTYWNOŚĆ TURYSTYCZNA ARGENTYŃSKIEJ POLONII NA PRZYKŁADZIE MIESZKAŃCÓW BUENOS AIRES}

Aktywność turystyczna to ogół czynności oraz działań ludzi związanych z ich uczestnictwem w turystyce. W odniesieniu do konkretnych wyjazdów jest to proces, który zaczyna się na długo, zanim nastąpi dany wyjazd oraz trwa zwykle jeszcze pewien czas po powrocie (Alejziak, 2011). Według W. Alejziaka można wyróżnić cztery podstawowe etapy aktywności turystycznej:

- powstanie i spostrzeganie określonych potrzeb, które w powiązaniu z motywami przekształcają się w cele wyjazdów, generując aktywność turystyczną,

- gromadzenie informacji i podejmowanie decyzji o podjęciu aktywności turystycznej,

- samo uczestnictwo w turystyce (wyjazd - pobyt - powrót),

- zachowania związane z uczestnictwem w turystyce, które następują po powrocie z wyjazdu.

Opisując aktywność argentyńskiej społeczności, niewątpliwie należy scharakteryzować grupę badawczą. W badaniu wzięło udział 50 respondentów. 64\% stanowiły kobiety, a 36\% mężczyźni. 4\% stanowiła grupa badawcza w wieku 16-19 lat, 6\% to osoby w wieku 20-24 lat, a 8\% ankietowanych to osoby w wieku 25-29 lat. Powyższa grupa badawcza to osoby o polskich korzeniach, które są bardziej Argentyńczykami niż Polakami. Urodziły się one w Argentynie, na co dzień posługują się językiem hiszpańskim, uczęszczały bądź uczęszczają do argentyńskiej szkoły, ale znają i kultywują polskie tradycje wyniesione $\mathrm{z}$ domu.

Kolejną grupą wiekową były osoby w wieku 30-39 lat, co stanowiło 16\% wszystkich badanych osób. Posługują się one językiem polskim w życiu codziennym oraz kultywują polskie tradycje. 32\% badanych stanowiły osoby w wieku 40-49 lat, wśród nich są nauczyciele Polskiej Szkoły Sobotniej i siostry zakonne. Aktywnie uczestniczą oni w życiu kulturalnym społeczności polskiej w Argentynie. 24\% badanych stanowiły osoby w wieku 50-60 lat, a 12\% to osoby w wieku 61-70 lat. Osoby należące do starszych przedstawicieli polskiej diaspory przyjechały do Argentyny po wojnie, najlepiej posługują się językiem ojczystym oraz w swej pamięci sięgają do historii i tradycji polskiej.

Jednym z pytań, które zostało zadane respondentom, było pytanie związane z częstotliwością podróżowania. Częstotliwość podróżowania Polonii argentyńskiej została określona na podstawie odpowiedzi na pytania: „Jak często bierze Pan/Pani udział w wyjazdach turystycznych?”, „,Ile razy w ciągu ostatnich lat był Pan/była Pani w Polsce?", „Jak długo trwał Pana/Pani pobyt w Polsce?”, „W jakich miesiącach wyjeżdża Pan/Pani najczęściej?". 12\% badanych udzieliło odpowiedzi, że nie podróżuje wcale. $40 \%$ badanych podróżuje raz w roku. Kolejne $40 \%$ respondentów to osoby, które podróżują dwa-pięć razy w roku. 8\% stanowią osoby, które podróżują więcej niż osiem razy w ciągu roku. Rycina 1 przedstawia częstotliwość uczestnictwa w wyjazdach turystycznych przez argentyńską Polonię.

Jeśli chodzi o pytanie „Ile razy w ciągu ostatnich dwóch lat był Pan/była Pani w Polsce?" to odpowiedzi przedstawiały się następująco. 26\% ankietowanych nie było w Polsce ani razu w ciągu ostatnich lat. Przyczyn tego należałoby szukać w odległości między Polską, a Argentyną, a także kosztach podróży, które są bardzo wysokie. 22\% ankietowanych odwiedziło Polskę przynajmniej raz w ciągu ostatnich dwóch lat, 10\% 
Rycina 1. Częstotliwość uczestnictwa w wyjazdach turystycznych przez argentyńską Polonię (w \%)

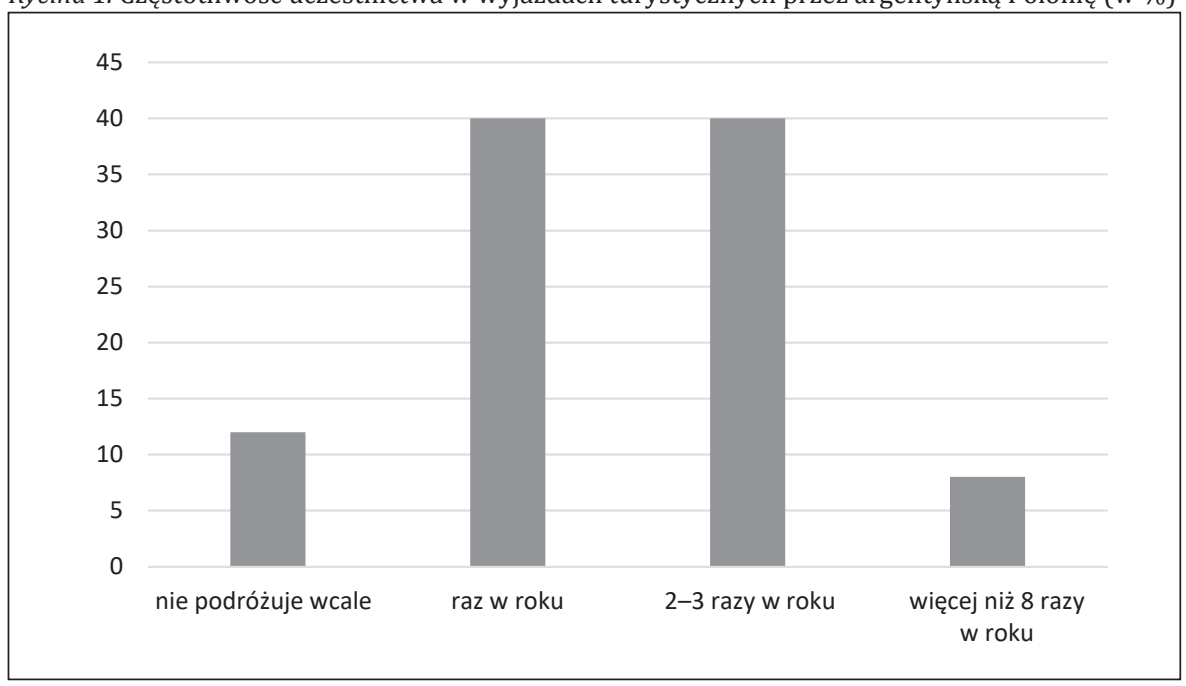

Źródło: opracowanie własne na podstawie własnych badań

ankietowanych było w Polsce dwa razy w ciągu ostatnich dwóch lat. $12 \%$ odwiedziło Polskę trzy razy, natomiast 30\% ankietowanych odpowiedziało, że odwiedziło Polskę więcej niż trzy razy w ciągu ostatnich dwóch lat.

Jeśli chodzi o długość pobytu ankietowanych w Polsce, to $12 \%$ z nich przebywało w kraju krócej niż tydzień. $6 \%$ badanych przebywało w Polsce tydzień, w przypadku $4 \%$ badanych pobyt trwał dwa tygodnie. $14 \%$ badanych udzieliło odpowiedzi, że przebywali w Polsce trzy tygodnie, 24\% ankietowanych to osoby, które były w Polsce aż miesiąc, a 26\% respondentów odpowiedziało, że przebywało w Polsce trzy miesiące. $14 \%$ ankietowanych odpowiedziało, że ich pobyt w Polsce trwał dłużej niż dwa miesiące. Respondenci najczęściej podróżują do Polski w styczniu, lutym i marcu. Związane jest to z tym, że w tych właśnie miesiącach w Argentynie trwa lato, są najwyższe temperatury, dzieci mają wakacje, a dorośli korzystają z urlopów. W odpowiedziach pojawiły się także takie miesiące, jak czerwiec, lipiec i sierpień. Wówczas w Argentynie jest zima i krótkie ferie zimowe, dlatego argentyńska Polonia, przyzwyczajona do ciepłych klimatów, chętnie odwiedza Polskę właśnie w tym czasie.

\section{MotyWY PODRÓŻOWANIA ARgENTYŃSKIEJ POLONII}

R. Faracik, W. Kurek, M. Mika, E. Pitrus i D. Ptaszycka-Jackowska (2008) wyróżniają sześć podstawowych rodzajów aktywności turystycznej: poznawczą, wypoczynkową, zdrowotną, kwalifikowaną, religijną i biznesową. Klasyfikacja ta, zmodyfikowana i dopasowana do motywów wyjazdów Polonii mieszkającej w Buenos Aires, stała się podstawą przygotowania pytań o rodzaje turystyki uprawianej przez badanych, zawartych w kwestionariuszu. Z uwagi na to, że autorki artykułu pytały, jaki rodzaj wyjazdów jest dominujący wśród argentyńskiej Polonii, wyjazdy te zostały podzielone na cztery kategorie. Były to wyjazdy krajowe, wyjazdy zagraniczne, wyjazdy zagraniczne - tylko do Polski, oraz wyjazdy krótkoterminowe (weekendowe). Każda z tych kategorii wyjazdowych scharakteryzowana jest oddzielnie. 
Rycina 2. Cel wyjazdów turystycznych argentyńskiej Polonii - wyjazdy krajowe (w \%)

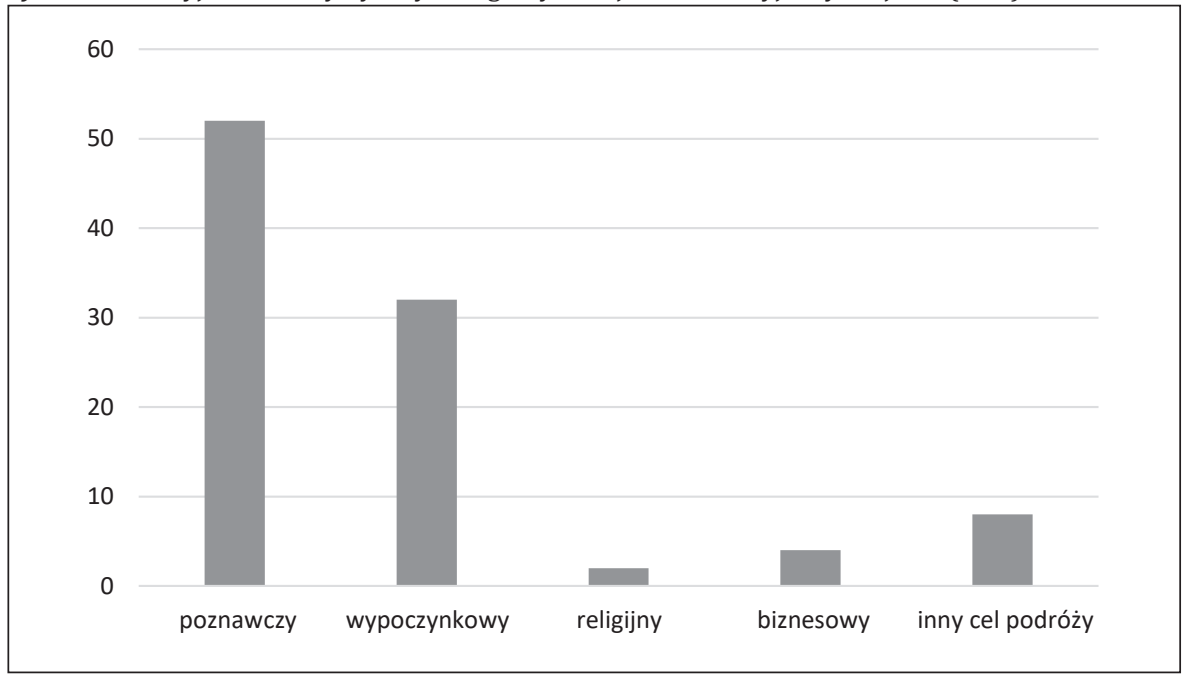

Źródło: opracowanie własne na podstawie własnych badań

Rycina 3. Cel wyjazdów turystycznych argentyńskiej Polonii - wyjazdy zagraniczne (w \%)

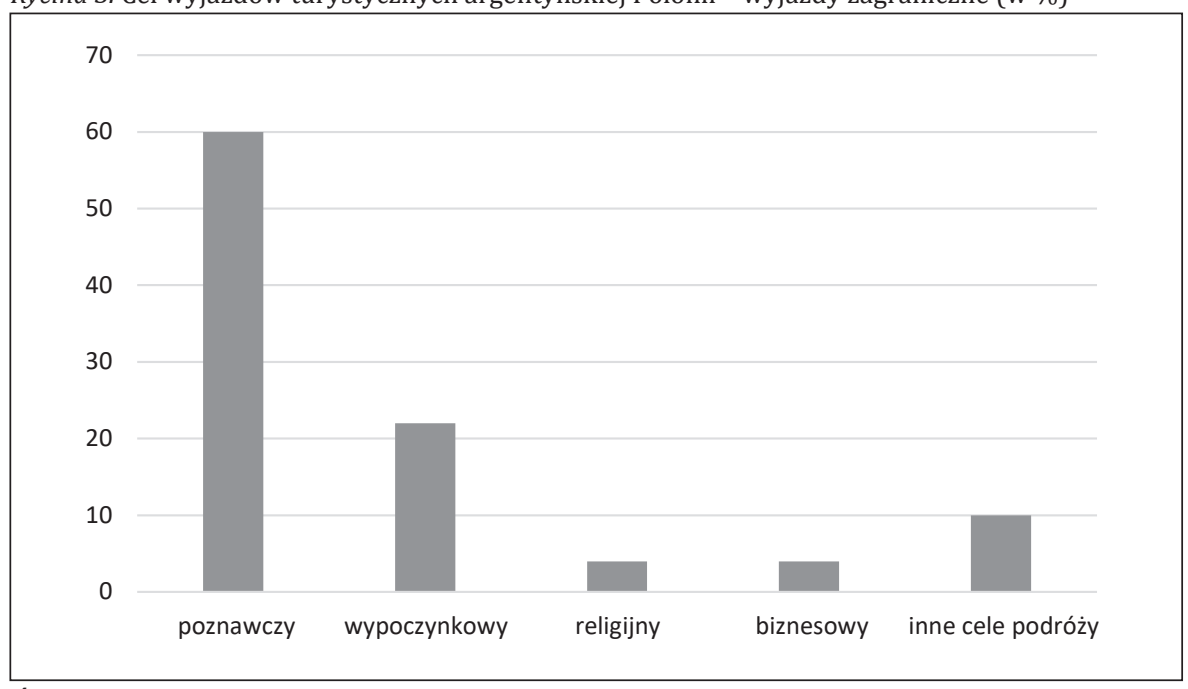

Źródło: opracowanie własne na podstawie własnych badań

W tej części artykułu została podjęta próba odpowiedzi na pytanie, jaki rodzaj turystyki preferuje Polonia mieszkająca w Buenos Aires, z podziałem na poszczególne rodzaje wyjazdu. Aby udzielić odpowiedzi na te pytania na podstawie uzyskanych wyników, poszczególnym rodzajom turystyki przyporządkowano rangi. Ankietowani mieli do wyboru następujące rodzaje aktywności turystycznej: poznawczy, wypoczynkowy, religijny, biznesowy oraz inny.

Jeśli chodzi o wyjazdy krajowe (Argentyna), to najwięcej osób podróżuje w celu poznawczym. Tak odpowiedziało 52\% ankietowanych, kolejno 32\% podróżuje w celu wypoczynkowym. 2\% respondentów podróżuje w celu religijnym, 4\% w celach 
Rycina 4. Cel wyjazdów turystycznych argentyńskiej Polonii - wyjazdy zagraniczne - do Polski (w \%)

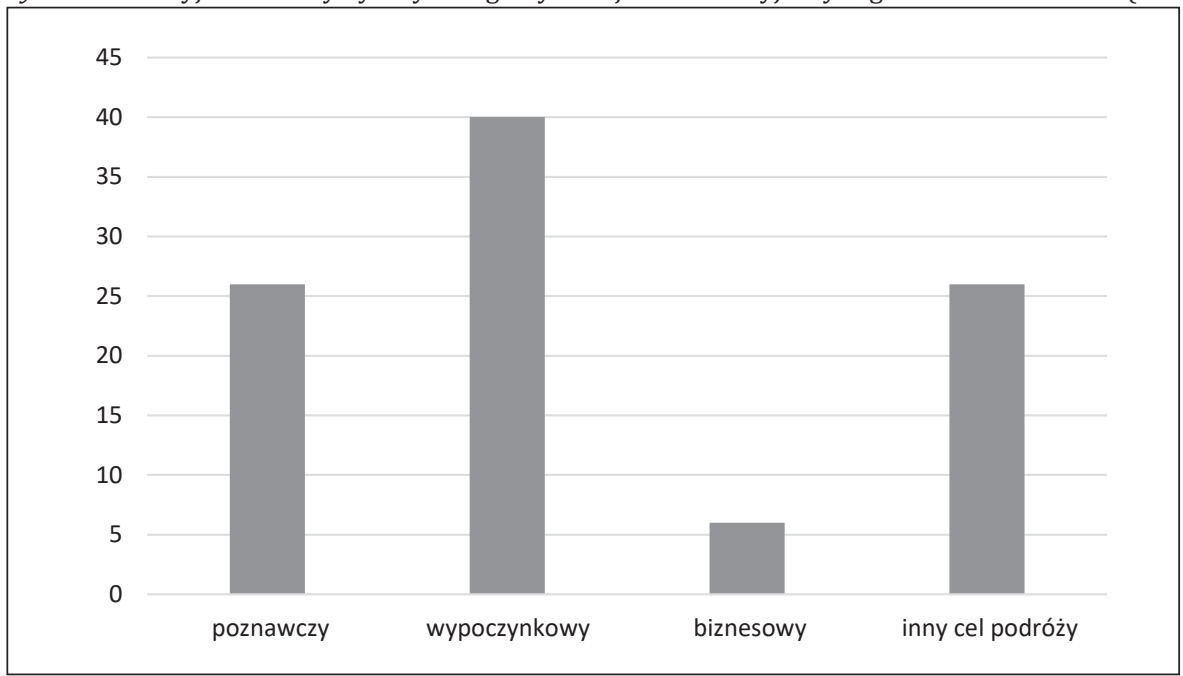

Źródło: opracowanie własne na podstawie własnych badań

Rycina 5. Cel wyjazdów turystycznych argentyńskiej Polonii - wyjazdy weekendowe (w \%)

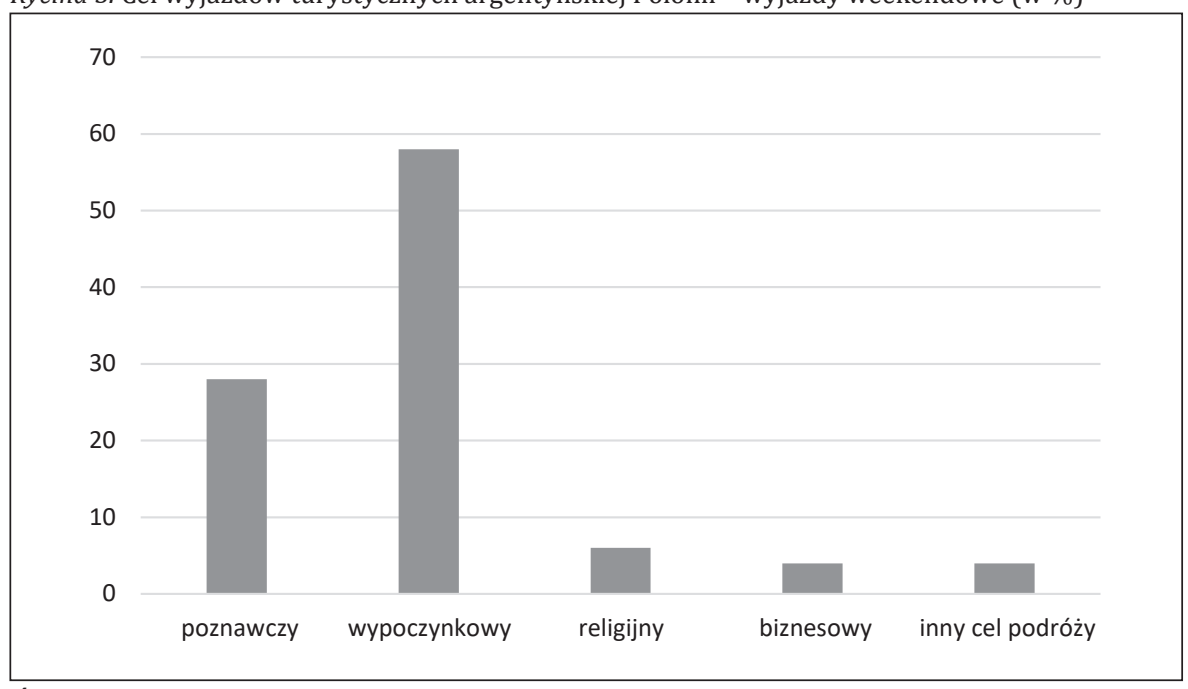

Źródło: opracowanie własne na podstawie własnych badań

biznesowych, a 8\% to osoby, które podróżują w celu odwiedzin znajomych rodziny, wolontariatu, a także w celach edukacyjnych. Rycina 2 przedstawia motywy wyjazdów krajowych argentyńskiej Polonii.

Podobnie sytuacja przedstawia się w przypadku wyjazdów zagranicznych. $60 \%$ respondentów udzieliło odpowiedzi, że podróżuje w celach poznawczych, 22\% - wypoczynkowych, 4\% - religijnych, 4\% - biznesowych. 10\% ankietowanych to osoby, które podróżują w celu odwiedzin rodziny, przyjaciół lub nie podróżują wcale poza granicę Argentyny. Odpowiedzi na to pytanie przedstawia rycina 3. 
W przypadku wyjazdów turystycznych do Polski (rycina 4) w 26\% procentach ankietowani podróżują w celu poznawczym, znaczna większość, bo aż 40\% ankietowanych - w celu wypoczynku. Żadna z osób, które wzięły udział w ankiecie, nie podróżuje do Polski w celach religijnych. 6\% ankietowanych to osoby, które odwiedzają Polskę w celach biznesowych. 26\% ankietowanych odpowiedziało, że podróżuje do Polski w innych celach niż wyżej wymienione: w celu odwiedzin rodziny i przyjaciół (turystyka sentymentalna).

W przypadku wyjazdów weekendowych, przynajmniej z jednym noclegiem poza miejscem zamieszkania (rycina 5). 28\% ankietowanych podróżuje w celach poznawczych, 58\% wypoczynkowych, $6 \%$ religijnych, $4 \%$ to osoby, które podróżują w celach biznesowych. $4 \%$ odpowiedziało, że wyjeżdża w celach rozrywkowych.

Na podstawie powyższych wyników badań ankietowych można stwierdzić, że bardzo popularnym motywem podróżowania jest motyw poznawczy. Daje on możliwość pogłębiania wiedzy o kraju i świecie, a także rozwoju, wzbogaca wiedzę z różnych dziedzin, pozwala na posługiwanie się językami obcymi, jest doskonałą okazją do zetknięcia się z inną kulturą i poznania jej. Kolejnym motywem podróżowania jest motyw wypoczynkowy - to doskonała okazja do zregenerowania sił, odpoczynku. Podróżowanie religijne ma na celu odwiedzanie miejsc świętych, ważnych religijnie, a podróżujący skupiają się wtedy na modlitwie. Wśród ankietowanych znajdują się także osoby, które podróżują w celach biznesowych - są to podróże, podczas których główną rolę odgrywa praca. W ramach tej turystki odbywają się spotkania grupowe i prywatne, wystawy, targi, które dotyczą branży biznesowej. Ankietowani wymieniali wśród innych motywów: podróże sentymentalne do rodziny (ten motyw pojawiał się głównie w przypadku podróżowania do Polski) oraz motyw rozrywkowy w przypadku podróży krótkoterminowych lub weekendowych.

\section{ORGANIZACJA TURYSTYKI PRZEZ ARGENTYŃSKĄ POLONIĘ}

Istotną rolę w turystyce odgrywa przemieszczanie się turystów do miejsc atrakcyjnych turystycznie. Ważnym elementem podczas podróżowania jest wybór środka transportu.

Na pytanie: „Jakim środkiem transportu najczęściej Pan/Pani podróżuje?” 42\% ankietowanych odpowiedziało, że podróżuje samochodem. Większość argentyńskich rodzin ma bowiem samochód, a podróż nim jest komfortowa (w każdej chwili można skorygować wcześniej ustalony plan podróży, można też zabrać więcej rzeczy) i tańsza niż transport lotniczy. 32\% ankietowanych udzieliło odpowiedzi, że podróżuje samolotem. Dużą zaletą transportu lotniczego jest krótszy czas podróżowania oraz komfort i bezpieczeństwo podczas podróży. Wybór przez ankietowanych samolotu jako środka transportu spowodowany jest przede wszystkim chęcią szybszego przemieszczania się po kraju oraz dalekimi destynacjami turystycznymi wybieranymi przez respondentów. $26 \%$ ankietowanych odpowiedziało, że podróżuje autobusem. Autobus to bardzo popularny i bardzo dobrze rozwinięty środek komunikacyjny w Argentynie. Autobusy są bardzo komfortowe i przygotowane do dalekich podróży, posiadają na przykład rozkładane siedzenia, dzięki czemu podczas długich podróży można wypocząć. Do popularnych argentyńskich przewoźników należą takie firmy, jak: Omnilineas oraz Teba SA. Rycina 6 przedstawia wybór środka transportu przez argentyńską Polonię. 
Rycina 6. Środek transportu wybierany przez argentyńską Polonię podczas podróżowania (w \%)

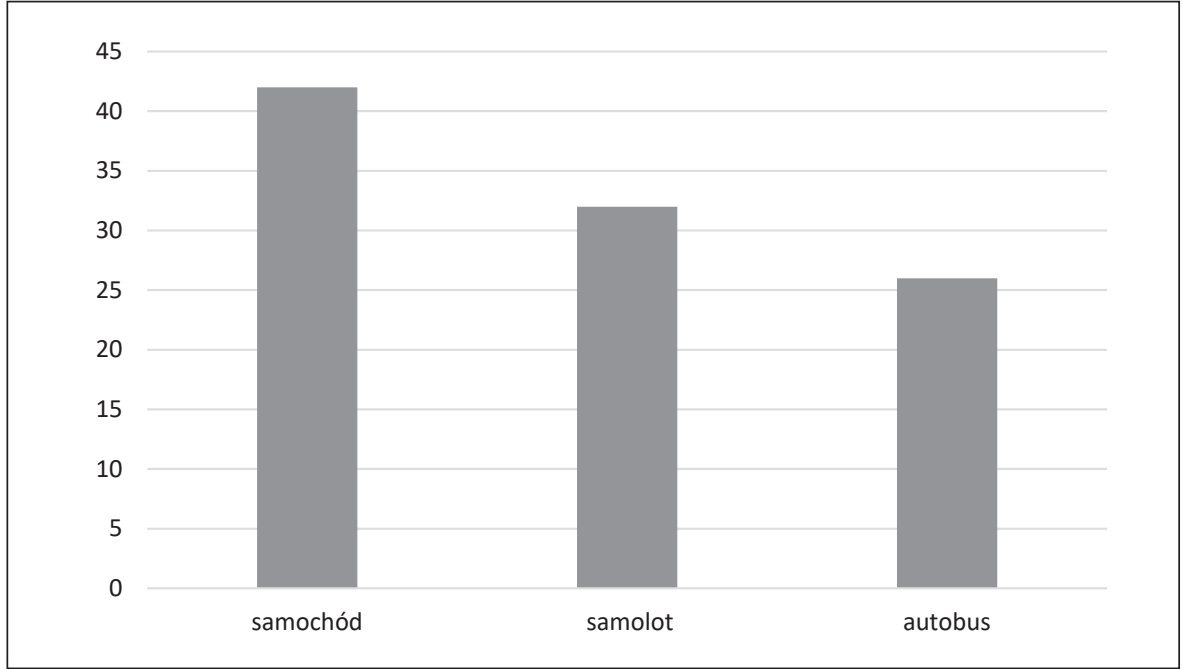

Źródło: opracowanie własne na podstawie własnych badań

Rycina 7. Rodzaj zakwaterowania wybierany przez argentyńską Polonię podczas podróżowania (w \%)

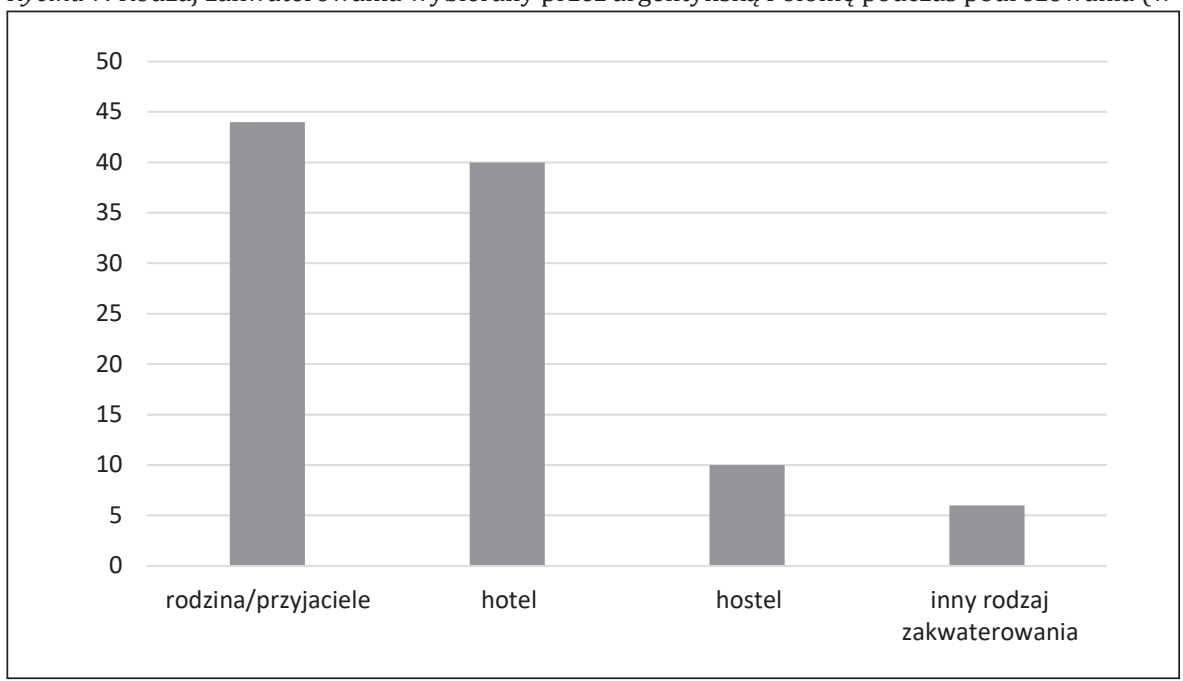

Źródło: opracowanie własne na podstawie własnych badań

Kolejnym ważnym elementem każdej podróży jest zakwaterowanie. Rycina 7 przedstawia najbardziej popularne rodzaje zakwaterowania wśród argentyńskiej Polonii. Na pytanie „Jaki rodzaj zakwaterowania preferuje Pan/Pani podczas podróży?” $44 \%$ ankietowanych odpowiedziało, że podczas podróży zatrzymuje się u rodziny lub przyjaciół. Kolejne $40 \%$ to osoby, które zatrzymują się w hotelu. 10\% ankietowanych to osoby, które wybierają hostel. Natomiast 6\% ankietowanych to osoby, które podczas podróży wynajmują mieszkanie lub korzystają z campingu. 
Rycina 8. Forma organizacji podróży przez argentyńską Polonię (w \%)

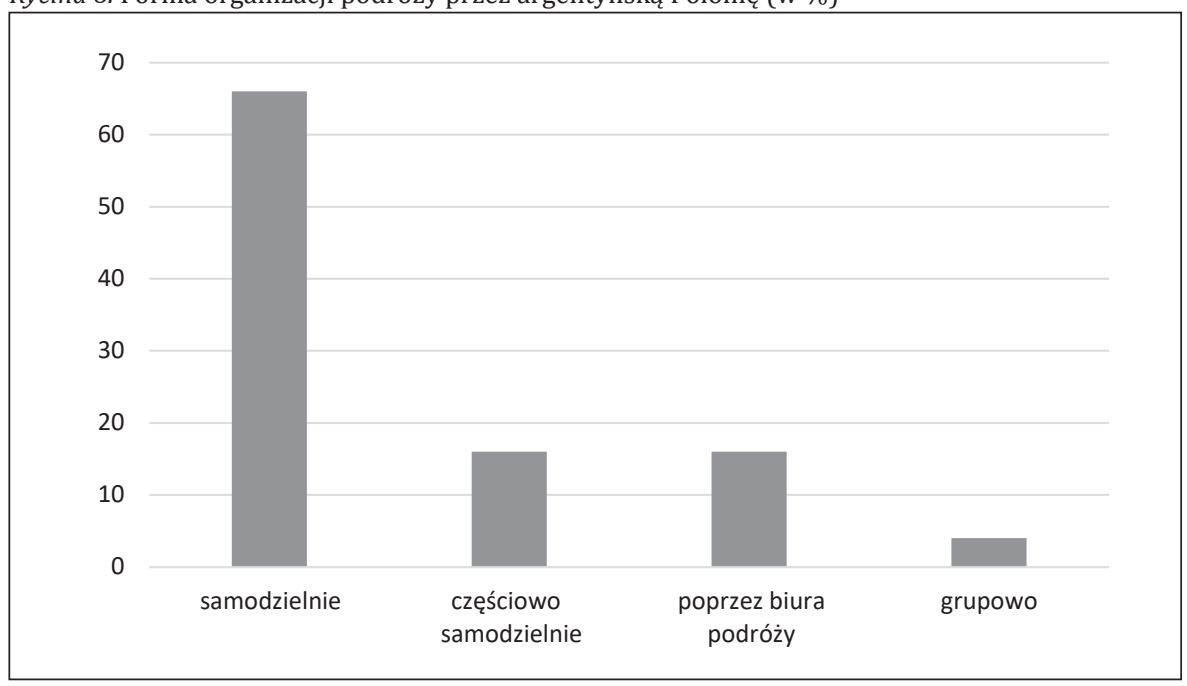

Źródło: opracowanie własne na podstawie własnych badań

Polonia argentyńska najczęściej podróżuje z rodziną (46\%), przyjaciółmi (26\%), partnerem (10\%). Wśród ankietowanych znalazły się również osoby, które podróżują same $(18 \%)$.

Jeśli chodzi o organizację wyjazdów (rycina 8), argentyńska Polonia najczęściej organizuje swoje podróże samodzielnie, aż 66\% ankietowanych udzieliło takiej odpowiedzi. 16\% ankietowanych to osoby, które organizują wyjazdy częściowo samodzielnie, czyli korzystają z pomocy biura podróży i kupują za ich pośrednictwem usługi związane z zakwaterowaniem podczas wyjazdu, a dojazd na miejsce organizują sobie same. Kolejne $16 \%$ przy organizacji podróży w całości korzysta z pomocy biur podróży. 4\% ankietowanych udzieliło odpowiedzi, że organizują swoje podróże wspólnie, grupowo.

\section{PodsumOWANIE}

Argentyna ze względu na swoje zróżnicowanie przestrzenne jest bardzo atrakcyjna turystycznie. Za główny cel w badaniach autorki postawiły sobie zbadanie aktywności turystycznej argentyńskiej Polonii na przykładzie mieszkańców Buenos Aires. Jak wykazały pilotażowe badania ankietowe, argentyńska Polonia jest aktywna turystycznie i dużo oraz chętnie podróżuje. Około 40\% ankietowanych podróżuje dwa-trzy razy w roku. Najwięcej osób robi to w celach poznawczych i wypoczynkowych. Większość ankietowanych to osoby, które organizują swoje podróże samodzielnie, a podczas podróży najchętniej zatrzymują się u rodziny i przyjaciół.

Jednym z pytań w kwestionariuszu ankiety była prośba o wymienienie jednego miejsca w Argentynie, które kojarzy się respondentom z Polską. Najczęstszą odpowiedzią było Maciaszkowo (polski kościół oraz Polska Szkoła Sobotnia). Ważną rolę w życiu Polonii Argentyńskiej odgrywa Polska Misja Katolicka w Buenos Aires, uczestnictwo w niedzielnej mszy świętej w kościele pod wezwaniem Matki Boskiej Częstochowskiej oraz spotkania po mszy w gronie polonijnym. Spotkania te są doskonałą okazją do kontaktu z rodakami, podtrzymywania polskich tradycji, wymiany poglądów oraz dzielenia 
się swoimi wspomnieniami z podróży. Kolejnym miejscem, które argentyńskiej Polonii kojarzy się z Polską, jest miejscowość Wanda w prowincji Misiones. W Wandzie można spotkać ludzi, którzy mówią swobodnie po polsku, czują ducha ojczyzny, są też tacy, którzy nigdy nie byli w Polsce, a mimo to czują się Polakami. Uwagę przyjezdnych przyciąga też polski kościółek, na którym widnieje napis „Częstochowa”, co dwa tygodnie odbywają się w nim msze święte w języku polskim. Wśród odpowiedzi pojawia się także Barilioche, miejscowość porównywana przez argentyńską Polonię do Zakopanego. Oba miejsca są doskonałe do uprawiania sportów zimowych, oba charakteryzuje też górski krajobraz. Inne miejsca, które argentyńskiej Polonii kojarzą się z Polską, to położone nad Morzem Argentyńskim Mar de las Pampas, Mar del Plata, Cordoba, Luján, kojarzone z Polską głównie przez znajdującą się w podziemiach kościoła kaplicę z wizerunkiem Matki Boskiej Częstochowskiej oraz odbywające się coroczne pielgrzymki polonijne do Matki Bożej. Wśród odpowiedzi pojawiła się również taka, że nie można porównywać Polski do Argentyny, ponieważ to dwa zupełnie różne kraje i że nie ma takiego miejsca w Argentynie, które mogłoby się kojarzyć z Polską. Pomimo to, jak pokazują przeprowadzone badania, argentyńska Polonia czuje swoje polskie korzenie, a jednym z głównych celów podróżowania jest Polska, w przypadku której zasadniczym motywem odbywania podróżny jest motyw sentymentalny, rodzinny.

Polacy zamieszkujący Argentynę mają w 100\% poczucie polskiej tożsamości narodowej. Na pytanie, dlaczego czują się Polakami, respondenci odpowiadali, że urodzili się w Polsce i tam są ich korzenie oraz rodzina. Ich rodzice od zawsze dbali, aby dzieci były wychowywane według polskich zwyczajów, a w domu zawsze mówiono po polsku. Ankietowani odpowiadali, że są Polakami, a w ich żyłach płynie polska krew. Pojawiła się również odpowiedź ,,Jestem Polakiem, gdyż sprawy ojczyzny są dla mnie na pierwszym miejscu". Respondenci w swoich odpowiedziach zapewniają, iż troszczą się o to, aby ich dzieci i rodziny pamiętały o Polsce.

Praca autorek niniejszej pracy, pomimo tego że były to badania pilotażowe przeprowadzone na małej grupie osób, mające na celu weryfikację kwestionariusza ankietowego przed badaniami właściwymi, uzupełniły informacje o społeczności polskiej zamieszkującej Buenos Aires na polu kulturowym, społecznym, a przede wszystkim turystycznym.

Przeprowadzone badania potwierdziły, iż społeczeństwo polskie w Argentynie pamięta o Polsce, odwiedza ojczysty kraj, posługuje się językiem polskim oraz dba o polskie tradycje. Kontynuacja badań przewidziana jest na rok 2020 na większej grupie Polonii mieszkającej w Buenos Aires, reprezentującej różne środowiska oraz różne grupy wiekowe.

\section{Literatura \\ References}

Alejziak, W. (2011). Aktywność turystyczna: Międzynarodowe i krajowe zróżnicowanie oraz kwestia wykluczenia społecznego. Turyzm, 21(1-2).

Bernhardson, W. (2011). Argentyna. Przewodnik National Geographic. Warszawa: Wydawnictwo National Geographic.

Curuś, E. (1978). Polacy w Argentynie. Lublin: Polonijne Centrum Kulturalno-Oświatowe Uniwersytetu Marii Curie-Skłodowskiej w Lublinie.

Faracik, R., Kurek, W., Mika, M., Pitrus, E., Ptaszycka-Jackowska, D. (2008). Rodzaje i formy turystyki. W: W. Kurek (red.). Turystyka. Warszawa: Wydawnictwo Naukowe PWN. 
Groch, J., Mydela, R. (1999). Przeglądowy atlas świata - Ameryka Południowa. Kraków: Oficyna Wydawnicza.

Kruczek, Z. (2010). Kraje pozaeuropejskie - zarys geografii turystycznej. Kraków: Proksenia.

Kurek, W. (red.) (2011). Turystyka. Warszawa: Wydawnictwo Naukowe PWN.

Malinowski, M. (2005). Ruch polonijny w Argentynie i Brazylii w latach 1989-2000. Warszawa: Centrum Studiów Latynoamerykańskich, Uniwersytet Warszawski.

Nowak, S. (2007). Metodologia badań społecznych. Warszawa: Wydawnictwo Naukowe PWN.

Olszycki, M. (2014). Ziemia czerwonych drzew - Polacy z Ameryki Południowej. Warszawa: Biblioteka Iberyjska.

Paradowska, M. (1984). Podróżnicy i emigranci - szkice z dziejów polskiego wychodźstwa $w$ Ameryce Południowej. Warszawa: Wydawnictwo Interpress.

Podróże marzeń: Argentyna (2007). Warszawa: Biblioteka Gazety Wyborczej.

Pyzik, S.P. (2004). Polacy w Argentynie i w innych krajach Ameryki Południowej. Warszawa: Fundacja SEMPER POLONIA.

Romanowska-Kindziuk, B. (red.) (2004). Polonia argentyńska w piśmiennictwie polskim. Antologia. Buenos Aires-Warszawa: Muzeum Historii Polskiego Ruchu Ludowego.

UNWTO (2016). Tourism Highlights. Pozyskano z https://www.e-unwto.org/doi/book/10.18111 /9789284418145

Wróbel, A.H. (1991). Pod Krzyżem Południa, Buenos Aires. Polska Misja Katolicka w Martin Coronado.

Wróbel, A.H. (2004). Wkład Kościoła polskiego w ewangelizację Argentyny. Buenos Aires: Polska Misja Katolicka w Martin Coronado.

Ziółkowska-Weiss, K. (2017a). Czynniki ekonomiczne warunkujące aktywność i destynacje turystyczne chicagowskiej Polonii. Prace Komisji Geografii Przemysłu Polskiego Towarzystwa Geograficznego, 31(3), 32-49.

Ziółkowska-Weiss, K. (2017b). Czynniki społeczne warunkujące aktywność i destynację turystyczne chicagowskiej Polonii. Turyzm/Tourism, 27(2), 121-130.

Ziółkowska-Weiss, K. (2018). Aktywność i destynacje turystyczne Polonii mieszkającej w Wielkiej Metropolii Chicagowskiej. Kraków: Wydawnictwo Naukowe Uniwersytetu Pedagogicznego w Krakowie.

Kamila Ziółkowska-Weiss, dr, Uniwersytet Pedagogiczny w Krakowie, Instytut Geografii, Katedra Turystyki i Badań Regionalnych. Studiowała prawo oraz kulturoznawstwo z historią sztuki na Uniwersytecie Jagiellońskim. Jest również absolwentką geografii z podstawami przedsiębiorczości na Uniwersytecie Pedagogicznym w Krakowie. Ukończyła podyplomowe studia na Uniwersytecie Ekonomicznym w Krakowie na kierunku zarządzanie turystyką międzynarodową. W 2015 roku z wyróżnieniem obroniła pracę doktorską, tym samym uzyskując tytuł doktora nauk o Ziemi. Od 2012 roku pracuje w Katedrze Turystyki i Badań Regionalnych Uniwersytetu Pedagogicznego w Krakowie, prowadząc m.in. zajęcia z turystyki w Stanach Zjednoczonych Ameryki Północnej. Czynny pilot wycieczek. Autorka kilkudziesięciu publikacji naukowych. Główne zainteresowania naukowe to Polonia w Ameryce Północnej i Południowej, turystyka kulturowa oraz mniejszości narodowe w Polsce i w Ameryce Północnej.

Kamila Ziółkowska-Weiss, PhD, a graduate of Culture studies at the Jagiellonian University and of Geography at the Pedagogical University of Krakow. She has graduated from postgraduate studies in international tourism management at the Cracow University of Economics. Since 2012 she has been a research worker, acting as an assistant in the department of Tourism and Regional Studies at the Pedagogical University of Krakow. An active tour guide. The author of several academic publications. Her main academic interests are cultural tourism, ethnic groups in Małopolska and Polish minority in the USA.

ORCID: 0000-0001-6575-5314

Adres/address:

Uniwersytet Pedagogiczny w Krakowie

Instytut Geografii

Katedra Turystyki i Badań Regionalnych

ul. Podchorążych 2, 30-084 Kraków, Polska

e-mail: kamilazw@up.krakow.pl 
Ewelina Haras, licencjat, absolwentka Instytutu Geografii Uniwersytetu Pedagogicznego w Krakowie na kierunku turystyka i rekreacja, a obecnie studentka Instytutu Amerykanistyki i Studiów Polonijnych UJ, kierunek amerykanistyka, specjalność latynoamerykanistyka.

Ewelina Haras, bachelor, graduate of the Institute of Geography of the Pedagogical University of Krakow in the field of tourism and recreation, and currently a student of the Institute of American Studies and Polish Diaspora of the Jagiellonian University, majoring in American studies, specialising in Latin American Studies.

ORCID: 0000-0001-8902-9886

\section{Adres/address:}

Uniwersytet Jagielloński w Krakowie Instytut Amerykanistyki i Studiów Polonijnych

Rynek Główny 34

31-010 Kraków

e-mail: ewelinaharas@wp.pl 